\title{
Article \\ ReCODE to Re-Code: An Instructional Model to Accelerate Students' Critical Thinking Skills
}

\author{
Sitti Saenab ${ }^{1,2}{ }^{\mathbb{D}}$, Siti Zubaidah ${ }^{1, *}$, Susriyati Mahanal ${ }^{1}$ and Sri Rahayu Lestari ${ }^{1}$ \\ 1 Department of Biology, Faculty of Mathematics and Natural Science, Universitas Negeri Malang, \\ Malang 65145, Indonesia; sitti.saenab@unm.ac.id (S.S.); susriyati.mahanal.fmipa@um.ac.id (S.M.); \\ srirahayulestari@um.ac.id (S.R.L.) \\ 2 Science Education Study Program, Faculty of Mathematics and Natural Science, Universitas Negeri Makassar, \\ Jl. A.P. Pettarani, South Sulawesi, Makassar 90222, Indonesia \\ * Correspondence: siti.zubaidah.fmipa@um.ac.id
}

Citation: Saenab, S.; Zubaidah, S.; Mahanal, S.; Lestari, S.R. ReCODE to Re-Code: An Instructional Model to Accelerate Students' Critical Thinking Skills. Educ. Sci. 2021, 11, 2.

https://dx.doi.org/10.3390/ educsci11010002

Received: 28 November 2020 Accepted: 20 December 2020 Published: 23 December 2020

Publisher's Note: MDPI stays neutral with regard to jurisdictional claims in published maps and institutional affiliations.

Copyright: () 2020 by the authors. Licensee MDPI, Basel, Switzerland. This article is an open access article distributed under the terms and conditions of the Creative Commons Attribution (CC BY) license (https: / creativecommons.org/ licenses/by/4.0/).

\begin{abstract}
The instructional models that have been implemented in the classroom could not support the development of students' critical thinking skills. These instructional models can be well implemented if those models can facilitate students with meaningful learning experiences such as reading, connecting prior knowledge to new information being learned in the classroom as well as doing investigation-based activities, discussion activities, and evaluation activities. The authors conducted the research to develop a ReCODE (Reading, Connecting, Observing, Discussing, Evaluating) instructional model and valid, practical, and effective tools. The procedures for developing the model included the preliminary research phase, prototyping phase, and assessment phase. Data on the validity of the model were collected using expert validation instruments, while the practicality of the model was measured using the instruments for the model's component practicality and the model's implementation. The effectiveness of the model was examined using the critical thinking test and questionnaires. The model was implemented to first-year students from the Department of Biology Education, Universitas Negeri Makassar, in the even semester of 2018/2019. The results showed that ReCODE was (1) valid, in terms of the theory underlying the development of the model, the components of the model, and the instructional tools accompanying the model, (2) practical because it had feasible components, and the learning process could be carried out successfully, and (3) effective in improving student critical thinking skills; the model also received positive responses from the lecturer and the students. Thus, this study's findings suggest that the ReCODE instructional model can be applied in the classroom to facilitate critical thinking.
\end{abstract}

Keywords: ReCODE; critical thinking skills; instructional model

\section{Introduction}

Partnership for 21st Century Learning (P21) has developed a learning framework that identifies several competencies and skills essential for success in life and career; one of the skills is critical thinking [1]. Someone who thinks critically can identify problems, ask questions, convey an argument with ease, and find various information [2]. Critical thinking skills can help a person deal with social, scientific, and practical problems effectively [3]. Critical thinking brings the right way of thinking and working, allows a person to be more accurate and specific in recognizing what is relevant, and is useful in problem solving and project management [4]. Critical thinking skills contribute to success at a higher level of education because higher education has defined critical thinking skills as the graduates' primary skills [5-8].

Research shows that university students in Indonesia have poor critical thinking skills. The students' lack of critical thinking may result from passive learning that cannot promote student engagement [9]. Moreover, in a critical thinking test, pre-service Biology teachers performed poorly by achieving an average score of 61.39 with the lowest score (27.14) 
observed in the "drawing conclusions" indicator and the highest score (79.39) found in the "evaluating arguments" indicator [10]. Several other related studies suggested that students' critical thinking in universities needs to be developed [11-15].

The observations indicate that the empowerment of critical thinking skills tends to below [16] is in line with this study results found that lecturers rarely plan or perform activities that can facilitate critical thinking. Biology learning is apt to sharpen students low order of thinking skills limited to remembering and understanding a concept [17]. Traditional learning still dominates learning processes with the lecture method.

Critical thinking in Biology needs to be developed since it is useful for analyzing the biology system's complexity. Biology includes studying living things and their interactions with the environment to form complex systems that are hierarchical and consist of multilevel interactions [18]. The development of students' critical thinking in Biology is vital because it constitutes an integral part of the natural sciences. Biology learning has the potential to facilitate learners' critical thinking. Plant Morphology is one of the branches of Biology that is a prerequisite for joining other Biology courses such as Plant Anatomy and Plant Bio-systematics. Plant Morphology course aims to help students (1) analyze the relationship between the external and internal structures of plants as well as their functions, (2) understand the growth of plant organs, (3) describe the shape of every plant part and understand the terms associated with the shapes, and (4) implement the knowledge for various purposes. Enrolling in the Plant Morphology course allows students to think comprehensively to analyze the plant kingdom's phenomena. Comprehensive thinking is associated with students' ability to promote thinking skills. Through the implementation of appropriate learning instruction, it is expected that the Plant Morphology course can improve students' critical thinking skills.

Critical thinking is not innate; it needs to be stimulated and taught explicitly in the classroom $[19,20]$. The development of critical thinking helps students train their thinking skills [21]. It can be done through (1) explicit instruction or general programs, (2) embedded instruction, and (3) mixed programs [22]. Research on how direct instruction or general programs could improve students' critical thinking has been conducted. It showed that students can perform better in critical thinking when they are explicitly trained using learning activities embedded in a planned instructional model [23].

Lecturers in Indonesian universities, especially Biology lecturers, have applied various instructional models to improve students' critical thinking. Constructivist-based instructional models, such as Problem-Based Learning, Inquiry, Discovery, Project-Based Learning, and Cooperative Learning have been implemented in the classroom. Still, no significant improvement was observed in the students' critical thinking skills. Some research findings even reported unsatisfactory results of students' critical thinking tests from implementing Problem-Based Learning alone without being combined with other learning strategies [24,25]. In higher education, the implementation of Problem-Based Learning (PBL) was less efficient than the implementation of conventional learning strategies [26]. It is challenging to apply PBL in all classrooms, and PBL is not always compatible with all subjects taught in a university [27]. Another issue that may arise in PBL classrooms is that the students have difficulty dealing with problem solving due to a lack of background knowledge. It is only possible because the students have low motivation in reading. In addition, cooperative learning cannot provide better results if it is not combined with a different learning strategy [28]. When implementing a cooperative instructional model, lecturers will face difficulties in thoroughly assessing time constraints [29].

The fruitfulness of implementing an instructional model in the classroom depends on the quality of learning experiences provided for the students. The first learning experience that needs to be optimized in the learning process is reading. Reading aims to form thinking skills, including critical thinking through capturing, understanding, imagining, applying, and expressing ideas [30]. The second important learning experience is connecting prior knowledge and new knowledge to see the course material's relevance to real-life situations [31]. Another important thing is to provide students with meaningful 
learning experiences through observation or investigation-based activities [32]. Based on observations or investigations, students can continue exploring the material or the topic [33]. The fourth learning experience that students need to focus on during the learning process is discussing. Discussing will support student academic achievement through the development of critical thinking skills [34]. Fifth, students need to be competent at evaluating. Evaluating helps students develop critical thinking through self-reflection and self-assessment [35].

Based on the explanations above, it is clear that an instructional model and instructional tools that can facilitate critical thinking need to be developed. Instructional models will function properly if they provide meaningful learning experiences for students, such as reading, connecting background knowledge and new knowledge, observing, discussing, and self-evaluating. These learning experiences can be accommodated in an instructional model called ReCODE (Reading, Connecting, Observing, Discussing, and Evaluating). Therefore, this study aimed to develop a constructivist-based instructional model that can facilitate critical thinking.

\section{Methods}

This study was a Research and Development study that adopted the development model by Plomp, T. etc. [36]. It consisted of three main phases: preliminary research, prototyping phase, and assessment phase.

\subsection{Preliminary Research}

Preliminary research covered students' critical thinking profile investigations, instructional tools that can support the instructional model being developed, and instrument development.

1. Preliminary research on the instructional model. Empirically, this activity was conducted to analyze the instructional models used by Biology lecturers at FMIPA, Universitas Negeri Makassar (UNM), Makassar, Indonesia. At this stage, relevant learning theories underlying ReCODE and the instructional model's development were also analyzed. The empirical study was performed through interview and course syllabus analysis. The empirical study's result was a conceptual framework of ReCODE that can be applied to facilitate critical thinking.

2. Preliminary research on students' critical thinking profile and reading motivation. The students' critical thinking profile was obtained through a critical thinking test, while the students' reading motivation was examined by administering a questionnaire to Biology students at FMIPA, UNM, Makassar, Indonesia.

3. Preliminary research on the instructional tools used in the Plant Morphology course at the Department of Biology Education, FMIPA, UNM. The instructional tools that were investigated included the course syllabus, lesson plan, worksheet, and assessment. The result of the analysis was thus used to develop new instructional tools suitable for the characteristics of ReCODE and that can be applied at UNM.

4. Preliminary research on instrument development. The instrument development theories analysis was also conducted to support the development of the ReCODE instructional model regarding data validity, practicality, and effectiveness.

\subsection{Prototyping Phase}

The prototyping phase consisted of the design stage, the realization of the prototype construction, and product validation and revision. The activity conducted at the design stage was to design the components of ReCODE included syntax, social system, reaction principle, supporting system (the conditions required for the implementation of the model, such as classroom setting, instructional system, instructional tools, learning facility, and media), and instructional impact (instructional and nurturant effect). The format of product validation and observation sheets was adapted from Arsyad, N. [37]. The design of instruments consists of a questionnaire and a critical thinking test. The students' responses 
to the test were assessed using a critical thinking rubric (with a reliability score of 0.896) modified from Zubaidah, S. etc. [38] and referred to Finken and Ennis (2001).

The realization of the prototype was the follow-up of the prototyping stage. At this stage, the initial prototypes of the ReCODE model, instructional tools, and research instruments were generated. The realization of the ReCODE instructional model consisted of (a) planning the learning steps (syntax), (b) determining the social system, (c) organizing the reaction principle, (d) determining the supporting system, and (e) organizing the instructional impacts. The realization of the ReCODE instructional tools consisted of (a) lesson plan that contained identity, learning objective(s), indicator(s), instructional model, learning steps, learning tools, and resources and assessment and (b) worksheet. The realization of the research instruments consisted of (a) validation sheet format, (b) observation sheet, (c) student questionnaire, (d) questionnaire, and (e) critical thinking test instrument.

The activity conducted at the validation stage was to validate and revise prototype 1 to generate prototype 2 that was then tried out at the assessment phase. Three experts (two experts in the instructional model and one expert in Plant Morphology) performed the instructional model's book's validation, instructional tools, and research instruments. The model's book's drafts, instructional tools, and research instruments were given to the experts for evaluation. Product revision was thus made according to the suggestions from the experts. The category of product validation is shown in Table 1.

Table 1. Category of product validation [37].

\begin{tabular}{cc}
\hline Score & Category \\
\hline $1 \leq \mathrm{Va}<2$ & Not Valid \\
$2 \leq \mathrm{Va}<3$ & Slightly Valid \\
$3 \leq \mathrm{Va}<4$ & Fairly Valid \\
$4 \leq \mathrm{Va}<5$ & Valid \\
$\mathrm{Va}=5$ & Very Valid \\
\hline
\end{tabular}

$\overline{\mathrm{Va}}=$ mean score.

A small group tryout was conducted for three meetings on Animal Structure material to identify problems that appeared during the ReCODE instructional model implementation. According to the expert validation and small group tryout results, revisions were made to generate prototype 2 .

\subsection{Assessment Phase}

The assessment phase aimed to investigate the practicality and effectiveness of the ReCODE instructional model. The data on the product's practicality was the model's components' compliance and the learning process conducted using the model. Meanwhile, the product's effectiveness was seen from the N-gain score achieved after implementing the instructional model and obtained from the lecturer's and students' responses toward the implementation of ReCODE. The ReCODE instructional model was implemented in the Plant Morphology course for 11 meetings. Eight observers observed the implementation of the model. The model's implementation employed one group pretest-post-test design (Table 2). The pretest was conducted in the first meeting to examine the students' initial critical thinking skills.

Table 2. Design of the study [39]. ReCODE: Reading, Connecting, Observing, Discussing, Evaluating.

\begin{tabular}{ccc}
\hline $\mathbf{0 1}$ & $\mathbf{X}$ & $\mathbf{O 2}$ \\
\hline Pretest & Treatment (ReCODE) & Post-test \\
\hline
\end{tabular}




\subsubsection{Participants}

The experimental study participants were 38 students (from Class B) registered in the even semester of 2019/2020 at the Department of Biology Education, UNM, Makassar, Indonesia. All of the participants stated their informed consent to participate in the study before doing the pretest. The Dean approved the Faculty of Mathematics and Natural Sciences, UNM (Number: 2066A/UN36. 1/PG/2019).

\subsubsection{Data Analysis}

The practicality of ReCODE was determined based on the criteria suggested by Hobri [40] shown in Table 3.

Table 3. Criteria of product feasibility.

\begin{tabular}{cc}
\hline Score & Criteria \\
\hline $1 \leq \mathrm{LF}<2$ & Not feasible \\
$2 \leq \mathrm{LF}<3$ & Less feasible \\
$3 \leq \mathrm{LF}<4$ & Quite feasible \\
$4 \leq \mathrm{LF}<5$ & Feasible \\
$\mathrm{LF}=5$ & Very feasible \\
\hline
\end{tabular}

LF = Level of feasibility.

The effectiveness of ReCODE was observed from the students' critical thinking scores after the implementation of the model. The critical thinking pretest and post-test results were analyzed using the normalized gain formula to obtain the N-gain score. The categorization of the $\mathrm{N}$-gain score analysis is presented in Table 4.

Table 4. Criteria of the N-gain score [41].

\begin{tabular}{cc}
\hline N-Gain Score & Criteria \\
\hline $0.30 \geq \mathrm{g}$ & Low \\
$0.70 \geq \mathrm{g}>0.30$ & Medium \\
$\mathrm{g}>0.70$ & High \\
\hline
\end{tabular}

ReCODE was considered effective in improving students' critical thinking if the mean $\mathrm{N}$-gain score achieved $>0.30$ or if it was in the medium or high category. The instructional model's effectiveness was also determined based on the lecturer and the students' responses. The model was considered effective if $70 \%$ of the students provided positive responses toward the model and if the lecturer responded positively to at least $70 \%$ of the questionnaire items on every aspect examined.

\section{Results}

\subsection{Preliminary Research}

\subsubsection{Preliminary Investigation on Instructional Models}

The results of the survey show that the lecturer had implemented constructivist-based learning. The results of the analysis of 10-course syllabi reveal that two out of the ten were direct learning models, six out of the ten were cooperative learning models, and two out of the ten were problem-based learning (PBL). Cooperative learning was the most widely used learning model at the university. However, several obstacles would be faced when the cooperative learning model was not combined with a different instructional strategy compatible with the model. One obvious obstacle is time inefficiency, leading to a flawed evaluation process and difficulty forming heterogeneous groups. The lecturer's interview also revealed that the lecturer had a problem instilling positive interdependence in the students. Therefore, integrated learning stages in group learning settings are highly recommended. Based on the survey results and the interview, it was concluded 
that problem-based learning became less effective when the students lacked background knowledge of the topic.

ReCODE instructional model was developed based on the constructivist learning paradigm, Piaget's cognitive development theory, Vygotsky's social interaction theory, J. Brunner's discovery learning theory, R. Gagne's nine event instruction, and D. Ausubel's meaningful learning theory $[42,43]$. The results of the preliminary research depict the importance of developing the ReCODE instructional model. Theoretically, the development of the ReCODE instructional model aimed to develop students' critical thinking.

\subsubsection{The Profile of the Students' Initial Critical Thinking Skills and Reading Motivation}

Despite their batch status, all Biology students from universities in South Sulawesi, Indonesia, had medium critical thinking scores. The statistical analysis results show no difference in terms of critical thinking between the first-, second-, and third-year students. This finding indicates that the universities had to improve the learning process so that the students could be empowered to think critically, for example, by developing an appropriate instructional model that can facilitate critical thinking.

The majority of the students from FMIPA, UNM, had good reading motivation 53 (73.61\%), less than half had fair reading motivation $15(20.83 \%)$, and only a few students had high reading motivation $4(5.56 \%)$, but no students had low reading motivation. This finding indicates that it was necessary to develop an instructional model or an instructional strategy to improve the students' motivation in reading.

\subsubsection{The Result of the Instructional Tools' Analysis}

The result of the instructional tools' analysis shows that the lecturer had been equipped with instructional tools in the form of a course syllabus, lesson plan, worksheet, and assessment tool. Still, these tools were insufficient to facilitate the students' critical thinking. The worksheet was irrelevant to the instructional model being implemented in the classroom. The cognitive assessment was focused more on measuring the students' cognitive knowledge, comprehension, and application.

\subsubsection{The Result of the Instrument's Analysis}

At the instrument's analysis stage, relevant theories on instrument development were analyzed to generate proper instruments that could be used to measure the validity, practicality, and effectiveness of the ReCODE instructional model. The instruments used to measure product validity were expert validation sheets of the ReCODE instructional model and instructional tools. The instruments used to examine the practicality of the model included assessing the feasibility of the model's components and the instrument for assessing the implementation of learning using ReCODE. The instruments used to measure the model's effectiveness included a critical thinking test, a lecturer questionnaire, and a student questionnaire.

\subsection{Prototyping Phase}

3.2.1. Product Development

The learning steps carried out in ReCODE consisted of Reading, Connecting, Observing, Discussing, and Evaluating. The syntax of the model is described in detail in Table 5. 
Table 5. Student activities in ReCODE.

\begin{tabular}{ccl}
\hline Syntax & & Student Activities \\
\hline Reading & - Students prepare themselves to learn by reading before class (conducted outside the school hours). \\
\hline Connecting & - Students connect the results of their reading to the topic being learned. \\
& - Students organize themselves into a group of 3-5. \\
\hline Observing & - Students conduct an observation in a group, use the worksheet to discover a concept. \\
& - Students perform an exploration/investigation activity to verify the concept. \\
\hline Discussing & - Students share the knowledge obtained at the observing stage through classroom discussion. \\
\hline Evaluating & - Students do a reflection on what they have learned and write it in a learning journal. \\
\hline
\end{tabular}

\subsubsection{The Expert Validation Result}

Experts evaluated the instructional model (ReCODE) to examine the support system, syntax, social system, the lecturer's role or tasks in organizing the lesson, support system, and instructional impacts. The expert validation results show that the model was valid with a score of 4.67 out of 5 . Thus, the model required minor revisions only. The results of the expert validation are presented in Table 6 .

Table 6. The expert validation results.

\begin{tabular}{ccc}
\hline Evaluated Aspects & Average Score & Criteria \\
\hline Supporting theories & 4.83 & Valid \\
Structure of the model & 4.87 & Valid \\
Syntax & 4.66 & Valid \\
Social system & 4.72 & Valid \\
Reaction principle & 4.80 & Valid \\
Supporting system & 4.50 & Valid \\
Instructional and nurturant effects & 4.50 & Valid \\
Implementation of learning & 4.71 & Valid \\
Learning environment and management tasks & 4.87 & Valid \\
Evaluation & 4.33 & Valid \\
\hline Total Average Score & 4.67 & Valid \\
\hline
\end{tabular}

Based on Table 6, it was concluded that ReCODE had included the aspects of an instructional model. However, product revision had to be focused on the language used in the book. The suggestion given by the validators was to use common language in student activities so that the ReCODE learning model can be generally accepted. In conclusion, the ReCODE instructional model was valid and thus could be implemented in the classroom. Furthermore, the lesson plan and the worksheet were also considered valid with the scores of 4.25 and 4.10, respectively. The validity of the lecturer and student questionnaires were also confirmed.

\subsubsection{The Result of the Instrument Validation}

The critical thinking test consisted of 15 essay questions on Plant Morphology. The validity test results show that the instrument was valid (10 questions) with a score of $0.327-0.682$ as seen in Appendix A. The instrument can be seen in Appendix B. The reliability test also showed that the instrument was reliable with $r=0.563$.

\subsection{Assessment Phase}

\subsubsection{The Practicality of ReCODE Instructional Model}

The data on the product's practicality consisted of the data on the model's compliance and the learning process's compliance using the model. 
1. Feasibility of the ReCODE Components

The analysis results on ReCODE syntax's feasibility, social system, reaction principle, and support system can be seen in Table 7.

Table 7. The feasibility of the ReCODE components.

\begin{tabular}{cccccc}
\hline & \multicolumn{5}{c}{ The Feasibility of the ReCODE Components } \\
\cline { 2 - 6 } Meeting No. & Syntax & $\begin{array}{c}\text { Social } \\
\text { System }\end{array}$ & $\begin{array}{c}\text { Reaction } \\
\text { Principle }\end{array}$ & $\begin{array}{c}\text { Support } \\
\text { System }\end{array}$ & Average \\
\hline 1 & 4.30 & 4.17 & 4.46 & 4.32 & 4.31 \\
2 & 4.37 & 4.22 & 4.46 & 4.32 & 4.34 \\
3 & 4.55 & 4.49 & 4.44 & 4.64 & 4.60 \\
4 & 4.75 & 4.51 & 4.53 & 4.67 & 4.62 \\
5 & 4.75 & 4.65 & 4.81 & 4.70 & 4.73 \\
6 & 4.80 & 4.72 & 4.84 & 4.86 & 4.80 \\
7 & 4.82 & 4.68 & 4.84 & 4.86 & 4.80 \\
8 & 4.78 & 4.56 & 4.68 & 4.60 & 4.65 \\
9 & 4.82 & 4.68 & 4.81 & 4.89 & 4.80 \\
10 & 4.80 & 4.75 & 4.81 & 4.85 & 4.80 \\
11 & 4.78 & 4.68 & 4.84 & 4.86 & 4.79 \\
\hline Average Score & 4.68 & 4.55 & 4.68 & 4.69 & 4.65 \\
\hline
\end{tabular}

Table 7 indicates that ReCODE obtained a score of 4.65 in terms of practicality, suggesting that the ReCODE instructional model was practical.

2. The Feasibility of the ReCODE Syntax

The results of the observation on the feasibility of the ReCODE implementation can be seen in Table 8 .

Table 8. Feasibility of the ReCODE syntax.

\begin{tabular}{cccccccc}
\hline No. & Reading & Connecting & Observing & Discussing & Evaluating & $\begin{array}{c}\text { Classroom } \\
\text { Environment }\end{array}$ & Average \\
\hline 1 & 4.71 & 4.21 & 4.08 & 4.00 & 3.87 & 4.25 & 4.20 \\
2 & 4.85 & 4.31 & 4.12 & 4.29 & 4.00 & 4.37 & 4.32 \\
3 & 4.57 & 4.26 & 4.08 & 4.04 & 4.00 & 4.25 & 4.20 \\
4 & 4.85 & 4.31 & 4.58 & 4.45 & 4.25 & 4.59 & 4.50 \\
5 & 4.85 & 4.34 & 4.58 & 4.45 & 4.75 & 4.65 & 4.60 \\
6 & 4.86 & 4.56 & 4.87 & 4.62 & 4.75 & 4.68 & 4.72 \\
7 & 4.85 & 4.72 & 4.87 & 4.63 & 4.87 & 4.68 & 4.77 \\
8 & 4.57 & 4.73 & 4.87 & 4.62 & 4.50 & 4.37 & 4.59 \\
9 & 4.71 & 4.68 & 4.70 & 4.65 & 4.75 & 4.56 & 4.67 \\
10 & 4.71 & 4.70 & 4.87 & 4.54 & 4.62 & 4.75 & 4.70 \\
11 & 4.71 & 4.70 & 4.75 & 4.62 & 4.62 & 4.75 & 4.69 \\
\hline Average & 4.74 & 4.50 & 4.57 & 4.44 & 4.52 & 4.53 & 4.55 \\
\hline
\end{tabular}

Table 8 shows that the average score obtained in each meeting was different. However, it had an upward trend, although there was a slight decrease observed in meeting 8 . The total average score of the syntax feasibility was 4.55 . Table 8 suggests ReCODE had practical syntax. 


\subsubsection{Effectiveness of the ReCODE Instructional Model}

The data of the model effectiveness were obtained through the N-gain test. The N-gain test result shows that the students' mean score of the post-test was higher than the pretest score (Table 9).

Table 9. The result of the $\mathrm{N}$-gain analysis.

\begin{tabular}{ccccc}
\hline $\begin{array}{c}\text { Instructional } \\
\text { Model }\end{array}$ & $\begin{array}{c}\text { Mean Score of } \\
\text { Pretest }\end{array}$ & $\begin{array}{c}\text { Mean Score of } \\
\text { Post-Test }\end{array}$ & N-Gain & Category \\
\hline ReCODE & 24.32 & 62.73 & 0.50 & Medium \\
\hline
\end{tabular}

Based on Table 9, it was known that the students experienced a $38.41 \%$ increase in critical thinking after being taught using ReCODE. The students' N-gain score was in the medium category (0.50), indicating that ReCODE effectively improved student critical thinking skills.

The effectiveness of the instructional model was also examined using the lecturer and student questionnaires. The average score of student responses was 4.15 , while the average scores of lecturer responses were 5.00 for the syntax, 5.00 for the social system, 4.75 for the reaction principle, 5.00 for the supporting system, and 5.00 for instructional and 4.75 for accompanying impacts. These data indicated that the students and the lecturer positively responded to the instructional model, ReCODE.

\section{Discussion}

This study showed that ReCODE was valid, practical, and effective in improving students' critical thinking skills as indicated by the N-gain medium score. According to the questionnaires' analysis, the lecturer and the students positively responded to the instructional model. These findings suggest that meaningful learning experiences can support the development of critical thinking. The increase in the students' critical thinking scores after implementing ReCODE is strongly associated with the model's learning stages, including reading, connecting, observing, discussing, and evaluating.

The first stage, reading, requires students to read before class to search for information regarding the topic that will be discussed in the classroom. Reading is a means of acquiring knowledge [44]. Reading is a complex process that requires the ability to recall and reflect on the previous memory [45]. Researchers agree that knowledge that is constructed during reading is obtained through cognitive strategies [46]. By practicing reading, students are encouraged to plan, understand, and monitor material and self-assessing $[47,48]$. Reading trains students to develop their thinking skills, and understanding a text can help improve learning effectiveness $[49,50]$.

At the second stage, connecting, students are provided with the opportunity to connect the reading activity results to the classroom topic. This activity shows a real-life phenomenon to the students and asks them challenging questions about the situation. It is important that the students can understand the relationship between real-life situations and information that they are going to learn [51]. The reading activity equips students with prior knowledge that can be used in the connecting stage. Prior knowledge contributes to an understanding of a particular topic [52]. Such constructivist-based activity will motivate students to relate background knowledge with the information shared during the learning process, thus indirectly affecting the students' thinking skills.

The third activity, observing, has the biggest contribution to improving students critical thinking skills. At this stage, students are asked to do an observation and discover a concept using a worksheet. The students are then encouraged to conduct the observation outdoors and use the result to verify the concept. Direct observations help students develop thinking skills by asking various questions [53]. In observing, the lecturer plays a role as a facilitator who guides the students. The lecturer may ask scaffolding questions to help students explore the concept, construct new knowledge, and organize arguments based on 
the evidence obtained from the exploration/investigation stage [54]. The questions can be in the form of leading, convergent, and divergent questions [55]. According to Averkieva, L etc. [56], critical thinking can be enhanced through scaffolding, motivation, and cooperative learning. Besides scaffolding, cooperative learning components are also included in the observing stage, where students work together in groups to discover a concept.

The fourth stage, discussing, provides the support of students' academic success. Social constructivist theory suggests that students must interact with each other to reflect on and develop thinking skills [57]. Discussion is a constructivist-based learning activity that can facilitate critical thinking [58]. The activities conducted at the discussing stage are sharing and giving presentations. Students can improve critical thinking during the discussion activity because they can directly confirm the presenters' knowledge. The interpretation and evaluation of information can also be found in students' attempts to present the topic. The discussion-presentation strategy is deemed useful in improving students' critical thinking $[59,60]$.

The fifth stage is evaluating. The success of learning can be identified through evaluation. At the end of the lesson, ReCODE students are encouraged to reflect on the learning process and put it into journal writing. Students' involvement in the reflection and evaluation activities allows them to develop critical thinking $[35,61,62]$. The discussion can be done in an online platform called Google Classroom to accommodate the lecturer's feedback. To reinforce student reflection, the lecturer should provide challenging, detailed, sincere, and friendly feedback [63]. Dialogue through Google Classroom also has the potential to foster critical thinking skills. Research by Koh, E. etc. [64] reported that organized dialogue in networking learning promotes critical thinking skills. In addition, the provision of an online platform can familiarize lecturers with practicing digital skills according to the technological, pedagogical, and content knowledge (TPACK) framework. This is in line with Pozo-Sánchez, S etc. [65] which stated that to develop pedagogical skills and content knowledge, the teachers/lecturer are also required to integrate technology in learning.

Based on the description above, the ReCODE model developed in this study is expected to improve the classroom's learning process, which will enhance the quality of education. It is also hoped that this study's results can provide information for readers who wish to conduct relevant research.

\section{Conclusions}

Based on the study results, it can be concluded that there was no difference in critical thinking between students from different batch groups in South Sulawesi; they were all in the medium category. The majority of the students had good reading motivation, less than half of the students had proper reading motivation, and only a few students had high reading motivation. The course syllabus analysis also showed that lecturers rarely used innovative learning methods that can improve students' poor critical thinking skills. It is necessary to improve the learning process in higher education by implementing various strategies to empower thinking skills or developing a learning model to enhance students' thinking skills. The ReCODE learning model developed in this study was proven valid, practical, and effective in improving students' critical thinking skills.

According to experts, ReCODE was valid in terms of content, syntax, social system, the lecturer's role or task in management, support system, and instructional impacts. This instructional model was also deemed practical because the model's components and learning stages were feasible and effective because it can improve students' critical thinking skills. Therefore, it is recommended to implement ReCODE in the classroom to facilitate student critical thinking development. This study was limited to higher education; thus, future studies may consider exploring the effectiveness of ReCODE in middle schools. The instructional model, ReCODE, should also be applied to various disciplines besides Biology. 
Author Contributions: Conceptualization, S.S., S.Z., S.M., and S.R.L.; formal analysis, S.S. and S.Z.; methodology, S.S., S.Z., and S.M.; writing-original draft, S.S. and S.Z.; writing-review and editing, S.S., S.Z., S.M., and S.R.L. All authors have read and agreed to the published version of the manuscript.

Funding: The Ministry of Research, Technology, and Higher Education of the Republic of Indonesia funded this study with contract number 19.3.7/UN32.14.1/LT/2019 and supported by the Education and Society Service Institution of Universitas Negeri Malang.

Institutional Review Board Statement: Ethical review and approval were waived for this study, due to reason that all students had agreed to participate in this study.

Informed Consent Statement: All of the participants stated their informed consent to participate in the study before doing the pretest. The Dean approved the Faculty of Mathematics and Natural Sciences, UNM (Number: 2066A/UN36. 1/PG/2019).

Data Availability Statement: All the data in this study were available.

Acknowledgments: We would like to send our deepest gratitude to the Ministry of Research, Technology, and Higher Education of the Republic of Indonesia, the Research and Community Service Institution of Universitas Negeri Malang, and Biology Department Universitas Negeri Makassar for the help so that this study could be completed on time.

Conflicts of Interest: The authors declare no conflict of interest. The funders did not take any part in the study's design; the collection, analyses, or interpretation of data; the writing of the manuscript, or the decision to publish the results.

\section{Appendix A. Instrument Validity Test Results}

Table A1. Instrument validity test results.

\begin{tabular}{cccc}
\hline Item & Pearson Correlation & Sig. (2-Tailed) & Remark \\
\hline Number 1 & 0.119 & 0.478 & Invalid \\
Number 2 & 0.682 & 0.000 & Valid \\
Number 3 & 0.308 & 0.060 & Invalid \\
Number 4 & 0.474 & 0.003 & Valid \\
Number 5 & 0.650 & 0.000 & Valid \\
Number 6 & 0.029 & 0.862 & Invalid \\
Number 7 & 0.605 & 0.000 & Valid \\
Number 8 & 0.604 & 0.000 & Valid \\
Number 9 & 0.332 & 0.042 & Valid \\
Number 10 & -0.039 & 0.817 & Invalid \\
Number 11 & 0.327 & 0.045 & Valid \\
Number 12 & 0.022 & 0.898 & Invalid \\
Number 13 & 0.605 & 0.000 & Valid \\
Number 14 & 0.478 & 0.002 & Valid \\
Number 15 & 0.586 & 0.000 & Valid \\
\hline
\end{tabular}

Value $p<0.05=$ valid, $r$ table $=0.320, r$-count $>r$ table $=$ valid.

\section{Appendix B. Instrument Test of Critical Thinking Skills}

1. There are two kinds of root systems, namely taproots and fiber roots. Based on its development, the two types of roots develop from the radicle. Why is it different when it grows?

2. Andi found plants with different leaf shapes. After reading the reference, he can explain that plant A leaves are single leaves, and the leaves of plant B are compound leaves. In your opinion, what feature he found and so that he could distinguish between the two plants? Also, explain why do some plants have single leaves while other plants have a compound leaf?

3. Pay attention to the leaves of the cassava plant (Manihot utilissima) and the kapok plant's leaves (Ceiba petandra). Give your analysis of the difference between the two leaves. 
4. In general, the branching on the stem's main axis is larger, frown which the growing branching appears. However, in Manila Sapodilla, it is very difficult to find the main axis. Why do you think this happened?

5. Tendril is a type of leaf modification found in certain plants. Why do you think there is a modification of the leaves into tendrils? Please explain. Which part of the plant will be modified into tendrils? Explain with pictures

6. In tropical forests of Asia, Africa, and America, various tree architectural models are found, but in European forests, there are only 2 types found, namely the rauh model and the troll model. In your opinion, why did this happen?

7. Joko peering the two flowers on the lawn. At first glance, the two flowers grow at the end of the stem, and there is only one flower on each stem. After Joko peering the details, it turns out that there is a difference between the two flowers, in which the rose is a single flower and the sunflower is a compound flower. In your opinion, why is sunflower classified as a compound flower?

8. When discussing fruit, it must not be separated from flowers because the fruit comes from flower development. If we are looking at the fruits of mango and pineapple, both come from compound flowers. However, being a fruit has a difference. There are many mango flowers, so there are many mangoes, but pineapples only become one fruit. In your opinion, why this happened. Please explain your answer!

9. Plants with stagnant stems such as nutgrass (Cyperus rotundus) are usually very easy to reproduce and sometimes uprooted can still grow new plants. In your opinion, why this happened? Please explain your answer!

10. Deby is observing two plants that have just grown from seed development. Deby's observations found that the cotyledons were attached to the stem of plant A (above the ground), while in plant B the cotyledons remained in the soil. Why do you think this happened?

\section{References}

1. Partnership for 21st Century, P21 Framework Definition. 2015. Available online: http:/ /www.p21.org/ (accessed on 12 March 2020).

2. Bailin, S.; Case, R.; Coombs, J.R.; Daniels, L.B. Conceptualizing Critical Thinking. J. Curric. Stud. 2010, 31, 285-302. [CrossRef]

3. Shakirova, D. Technology for the Shaping of College Students' and Upper-Grade Students' Critical Thinking. Russ. Educ. Soc. 2007, 49, 42-52. [CrossRef]

4. Cottrell, S. Critical Thinking Skills: Developing Effective Analysis and Argument; Palcrave Macmillan: London, UK, 2005.

5. Forawi, S.A. Standard-based Science Education and Critical Thinking. Think. Ski. Creat. 2016, 20, 52-62. [CrossRef]

6. Ahrari, S.; Abu Samah, B.; Hj Bin Hassan, M.S.; Abdul Wahat, N.W.; Zaremohzzabieh, Z. Deepening Critical Thinking Skills Through Civic Engagement in Malaysian Higher Education. Think. Ski. Creat. 2016, 22, 121-128. [CrossRef]

7. Ab Kadir, M.A. What Teacher Knowledge Matters in Effectively Developing Critical Thinkers in the 21st Century Curriculum? Think. Ski. Creat. 2017, 23, 79-90. [CrossRef]

8. Sellars, M.; Fakirmohammad, R.; Bui, L.; Fishetti, J.; Niyozov, S.; Reynolds, R.; Thapliyal, N.; Liu-Smith, Y.L.; Ali, N. Conversations on Critical Thinking: Can Critical Thinking Find Its Way Forward as the Skill Set and Mindset of the Century? Educ. Sci. 2018, 8, 205. [CrossRef]

9. Hadi, S.A.; Susantini, E.; Agustini, R. Training of Students' Critical Thinking Skills through the implementation of a Modified Free Inquiry Model. J. Phys. Conf. Ser. 2018. [CrossRef]

10. Saefi, M.; Suwono, H.; Susilo, H. Biology Student Teacher's Critical Thinking: An Exploration Study. In Proceedings of the International Conference on Education 2016 "Education in the 21st Century: Responding to Current Issues", Malang, Indonesia, 22-24 November 2016; pp. 605-612.

11. Fakhriyah, T. Penerapan Problem Based Learning dalam Upaya Mengembangkan Kemampuan Berpikir Kritis Mahasiswa [Application of Problem Based Learning in Develops Students' Critical Thinking Ability]. J. Pendidik. IPA Indones. 2014, 3, 95-101.

12. Alimah, S. Model Pembelajaran Eksperiensial Jelajah Alam Sekitar. Strategi untuk Meningkatkan Kemampuan Berpikir Kritis Mahasiswa [Experiential Learning Model Exploring the Environment. Strategies to Improve Students' Critical Thinking Ability]. J. Penelit. Pendidik. 2014, 31, 47-54.

13. Jirana; Amin, M.; Suarsini, E.; Lukiati, B. Analisis Keterampilan Berpikir Kritis Mahasiswa pada Matakuliah Evolusi di Universitas Sulawesi Barat [Analysis of Students' Critical Thinking Skills in the Evolution Course at the University of West Sulawesi]. In Proceedings of the Seminar Nasional Pendidikan dan Saintek; University of West Sulawesi: West Sulawesi, Indonesia, 2016; pp. 953-958.

14. Bustami, Y.; Corebima, A.D. The Effect of JiRQA Learning Strategy on Critical Thinking Skills of Multiethnic Students in Higher Education, Indonesia. Int. J. Hum. Soc. Sci. Educ. 2017, 4, 13-22. [CrossRef] 
15. Fitriani, H.; Asy'ari, M.; Zubaidah, S.; Mahanal, S. Exploring The Prospective Teachers Critical Thinking and Critical Analysis Skills. J. Pendidik. IPA 2019, 8, 379-390. [CrossRef]

16. Suwono, H.; Pratiwi, H.E.; Susanto, H.; Susilo, H. Enhancement of Students' Biological Literacy and Critical Thinking of Biology Through Socio-Biological Case-Based Learning. J. Pendidik. IPA Indones. 2017, 6, 213-220. [CrossRef]

17. Hidayati, N.; Irmawati, F.; Prayitno, T.A. Peningkatan Keterampilan Berpikir Kritis Mahasiswa Biologi Melalui Multimedia STEM Education [Improving Biology Students Critical Thinking Skills through STEM Multimedia Education]. JPBIO J. Pendidik. Biol. 2019, 4, 84-92.

18. Buckley, B.C.; Quellmalz, E.S. Supporting and Assessing Complex Biology Learning with Computer-Based Simulations and Representations. In Models and Modeling in Science Education 7; Treagust, D.F., Tsui, C.-Y., Eds.; Springer: New York, NY, USA, 2013; pp. 247-267.

19. Ahuna, K.H.; Tinnesz, C.G.; Kiener, M. A New Era of Critical Thinking in Professional Programs. Teach. Learn. J. 2014, 7, 1-9.

20. Persky, A.M.; Medina, M.S.; Castleberry, A.N. Developing Critical Thinking Skills in Pharmacy Students. Am. J. Pharm. Educ. 2019, 83, 1-22. [CrossRef] [PubMed]

21. Palennari, M.; Taiyeb, M.; Saenab, S. Profile of Students' Metacognitive Skill Based on Their Learning Style. J. Phys. Conf. Ser. 2018. [CrossRef]

22. Radulović, L.; Stančić, M. What is Needed to Develop Critical Thinking in Schools? Cent. Educ. Policy Stud. J. 2017, 7, 9-25.

23. Vieira, R.M.; Tenreiro-Vieira, C. Fostering Scientific Literacy and Critical Thinking in Elementary Science Education. Int. J. Sci. Math. Educ. 2016. [CrossRef]

24. Palennari, M. Potensi Integrasi Problem Based Learning dengan Pembelajaran Kooperatif Jigsaw dalam Meningkatkan Keterampilan Berpikir Kritis Mahasiswa [The Potential of Integrating Problem Based Learning with Jigsaw Cooperative Learning in Improving Students' Critical Thinking Skills]. Bionature 2012, 13, 1-9.

25. Bahri, A.; Idris, I.S.; Nurman, R.; Ristiana, E. PBLRQA Strategy Potential in Enhancing Metacognitive Skills of Students with Different Academic Achievement. J. Phys. Conf. Ser. 2019, 1317, 012199. [CrossRef]

26. Bahri, A.; Corebima, A.D.; Amin, M.; Zubaidah, S. Potensi Strategi Problem-based Learning (PBL) Terintegrasi Reading Questioning and Answering (RQA) Untuk Meningkatkan Hasil Belajar Kognitif Mahasiswa Berkemampuan Akademik Berbeda [The Potential of Integrated Problem-based Learning (PBL) Strategies Reading Questioning and Answering (RQA) to Improve Cognitive Learning Outcomes of Students with Different Academic Abilities]. J. Pendidik. Sains 2016, 2, 49-59.

27. Treagust, D.; Peterson, R.F. Learning to Teach Primary Science Trough Problem Based Learning. Sci. Educ. 1998, 82, $215-237$. [CrossRef]

28. Setiawan, D.; Susilo, H. Peningkatan Keterampilan Metakognitif Mahasiswa Program Studi Biologi melalui Penerapan Jurnal Belajar dengan Strategi Jigsaw Dipadu PBL Berbasis Lesson Study Pada Matakuliah Biologi Umum [Enhancing the Skills of Metakognitıf Mahasıswa Biolog1 Study Program through the Application of Learning Journals with Strateg1 Jigsaw combine PBL Based Lesson Study on General Biolog1 course]. In Proceedings of the Seminar Nasional “Peran Biologi dan Pendidikan Biologi dalam Menyiapkan Generasi Unggul dan Berdaya Saing Global”, Malang, Indonesia, 21 March 2015; pp. 359-369.

29. Gufran, A.M.; Ermawati, S. The Strengths and Weaknesses of Cooperative Learning and Problem Based Learning in EFL Writing Class: Teachers and Students' Perspectives. Int. J. Instr. 2018, 11, 657-672. [CrossRef]

30. Zubaidah, S.; Corebima, A.D.; Mahanal, S.; Mistianah. Revealing the Relationship between Reading Interest and Critical Thinking Skills through Remap GI and Remap Jigsaw. Int. J. Instr. 2018, 11, 41-56. [CrossRef]

31. Gredler, M.; Margaret, E. Learning and Instruction: Theory into Practice, 6th ed.; Pearson Education, Inc.: Clumbus, OH, USA, 2009.

32. Babadogan, C.; Ünal, F. Examples of Instructional Design for Social Studies According to Meaningful Learning and Information Processing Theories. Procedia Soc. Behav. Sci. 2011, 15, 2155-2158. [CrossRef]

33. Hunt, F. Exploring The News of Virtual Worlds for The Teaching and Learning Education of Development Education in Primary School; University of Dublin: Dublin, Ireland, 2012.

34. Mercier, E.; Higgins, S. Creating Joint Representations of Collaborative Problem Solving with Multi-Touch Technology. J. Comput. Assist. Learn. 2014, 30, 497-510. [CrossRef]

35. Bouldin, A.S.; Holmes, E.R.; Fortenberry, M.L. Blogging" about Course Concepts: Using Technology for Reflective Journaling in a Communications Class. Am. J. Pharm. Educ. 2006, 70. [CrossRef]

36. Plomp, T.; Nieveen, N. Educational Design Research: An Introduction; SLO: Enschede, The Netherlands, 2013.

37. Arsyad, N. Model Pembelajaran Matematika yang Menumbuhkan Kemampuan Metakognitif untuk Menguasai Bahan Ajar [Mathematics Learning Model That Fosters Metacognitive Ability to Master Teaching Materials]. Doctoral Dissertation, Universitas Negeri Surabaya, Surabaya, Indonesia, 2007.

38. Zubaidah, S.; Corebima, A.D.; Mistianah, M. Asesmen Berpikir Kritis Terintegrasi Tes Essay [Integrated Critical Thinking Assessment Essay Test]. In Simposium Nasional Pendidikan Biologi Bertema Edubiodiversity: Inspiring Education with Biodiversity; Universitas Ahmad Dahlan: Yogyakarta, Indonesia, 2015.

39. Sugiyono, S. Metode Penelitian Kuantitatif, Kualitatif dan RED [Quantitative Research Methods, Qualitative and RED]; Alfabeta: Bandung, Indonesia, 2011.

40. Hobri, H. Metodologi Penelitian Pengembangan (Aplikasi Pada penelitian Pendidikan Matematika) [Research Development Methodology (Application in Mathematics Education Research)]; Pena Salsabila: Jember, Indonesia, 2010. 
41. Hake, R. Analyzing Change/Gain Scores. 1999. Available online: http://www.physics.indiana.edu/ \{ $\}$ sdi/AnalyzingChangeGain.pdf (accessed on 20 May 2020).

42. Woolfolk-Hoy, A.E. Educational Psichology, 9th ed.; Active Learning Edition; Pearson Education: London, UK, 2005.

43. Schunk, D.H. Learning Theories an Educational Perspective, 6th ed.; Pearson Education, Inc.: London, UK, 2012.

44. Baki, Y. The Effect of Critical Reading Skills on the Evaluation Skills of the Creative Reading Process. Eurasian J. Educ. Res. 2020, 88, 199-224. [CrossRef]

45. Shihab, I.A. Reading as Critical Thinking. Asian Soc. Sci. 2011, 7, 209-218. [CrossRef]

46. Cubukcu, Z. Critical Thinking Dispositions of the Turkish Teacher Candidates. Turk. Online J. Educ. Technol. 2006, 5. Available online: http:/ / www.tojet.net/articles/544.htm (accessed on 15 May 2020).

47. Doolitte, P.E.; Hicks, D.; Triplett, C.F. Reciprocal Teaching for Reading Comprehension in Higher Education: A Strategy for Fostering the Deeper Understanding for texts. Int. J. Teach. Learn. 2006, 17, 106-118.

48. Bahri, A.; Idris, I.S.; Muis, H.; Arifuddin, M.; Fikri, M.J.N. Blended Learning Integrated with Innovative Learning Strategy to Improve Self-Regulated Learning. Int. J. Instr. 2020, 14, 779-794. [CrossRef]

49. Tung, C.; Chang, S.Y. Developing Critical Thinking through Literature Reading. Feng Chia J. Humanit. Soc. Sci. 2009, 19, 287-317.

50. Joyce, B.; Weil, M.; Calhoun, E. Models of Teaching, 9th ed.; Publishing as Allyn \& Bacon: Upper Saddle River, NJ, USA, 2016.

51. Akben, N. Suitability of Problem Scenarios Developed by Pre-service Teacher Candidates to Problem-Based Learning Approach. Eurasian J. Educ. Res. 2019, 82, 231-252. [CrossRef]

52. Tarchi, C. Fostering Reading Comprehension of Expository Texts through the Activation of Readers' Prior Knowledge and Inference-making Skills. Int. J. Educ. Res. 2015, 72, 80-88. [CrossRef]

53. Fusaro, M.; Smith, M.C. Preschoolers' Inquisitiveness and Science-relevant Problem Solving. J. Biol. Educ. 2018, 42, 119-127. [CrossRef]

54. Sen, S.; Yilmaz, A.; Geban, O. The Effect of Process Oriented Quided Inquary Learning Environment on Students Self Regulatled Learning Skills. Probl. Educ. 21st Century 2015, 66, 54-66.

55. Hanson, D.M. Instructor's Guide to Guided-Inquiry Learning by with Contributions from other POGIL Project Personnel: Instructor's Guide to Process-Oriented Guided-Inquiry Learning; Lisle: Clarinda, IA, USA, 2006.

56. Averkieva, L.; Chayka, Y.; Glushkov, S. Web Quest as a Tool for İncreasing Students Motivation and Critical Thinking Development. Procedia Sos. Behav. Sci. 2015, 206, 137-140. [CrossRef]

57. Flynn, A.E.; Klein, D.J. The Influence of Discussion Groups in a Case-Based Learning Environment. Educ. Technol. Res. Dev. 2001, 49, 71-86. [CrossRef]

58. Arend, R. Learning to Teach; McGrow-Hill Company, Inc.: New York, NY, USA, 2012.

59. Vieira, M.R.; Tenreiro-Vieira, C.; Martins, I. Critical Thinking: Conceptual Clarification and Importance in Science Education. Sci. Educ. Int. 2011, 22, 43-54.

60. Sahamid, H. Fostering Critical Thinking in the Classroom. Adv. Lang. Lit. Stud. 2014, 5, 165-172. [CrossRef]

61. Erdogan, F. Effect of Cooperative Learning Supported by Reflective Thinking Activities on Students' Critical Thinking Skills. Eurasian J. Educ. Res. 2019, 80, 89-112. [CrossRef]

62. Norton, F.; Gregson, M. The Thinking Skills Deficit: What Role Does a Poetry Group Have in Developing Critical Thinking Skills for Adult Lifelong Learners in a Further Education Art College ? Educ. Sci. 2020, 10, 73. [CrossRef]

63. Fund, Z. Effects of Communities of Reflecting Peers on Student-teacher Development-Including in-Depth Case Studies. Teach. Teach. Theory Pract. 2010, 16, 679-701. [CrossRef]

64. Koh, E.; Jonathan, C.; Tan, J.P.L. Exploring Conditions for Enhancing Critical Thinking in Networked Learning: Findings from a Secondary School Learning Analytics Environment. Educ. Sci. 2019, 9, 287. [CrossRef]

65. Pozo-Sánchez, S.; López-Belmonte, J.; Rodríguez-García, A.M.; López-Núñez, J.A. Teachers' Digital Competence in Using and Analytically Managing Information in Flipped Learning. Cult. Educ. 2020, 32, 1-35. [CrossRef] 